\title{
Assessment of the Soil Seed Bank Aiming at Transposition to Forest Regeneration in the Western Amazonia
}

\author{
Bruno Machado Araújo \\ Universidade Estadual do Maranhão Campus Balsas, Praça Gonçalves Dias, s/n 65.800-000 \\ Balsas - MA, Brazil. E-mail: ambiental.bruno@ hotmail.com \\ Anatércia Ferreira Alves \\ Universidade Estadual da Região Tocantina do Maranhão - UEMASUL Rua Godofredo \\ Viana, $N^{\circ}$ 1300, Centro, 65901-480 Imperatriz - MA, Brazil. \\ E-mail: anaterciaa@yahoo.com.br
}

\begin{abstract}
Paulo Alexandre Fernandes Rodriques de Melo
Universidade Estadual do Maranhão, Av. Lourenço Vieira da Silva, nº 1000 - Bairro: Jardim São Cristovão 65055-310 - São Luís - MA. Brazil.

E-mail: pauloalexandrefernandes@ outlook.com
\end{abstract}

Leonardo Hunaldo dos Santos

Universidade Federal do Maranhão, Centro, Imperatriz - MA. 65900-410 Brazil.

E-mail: leohunaldo@gmail.com

Mário Luiz Ribeiro Mesquita (Corresponding author)

Programa de Pós-Graduação em Agricultura e Ambiente, Universidade Estadual do Maranhão, Av. Lourenço Vieira da Silva, nº 1000 - Bairro: Jardim São Cristovão 65055-310 - São Luís - MA. Brazil. E-mail: mario-mesquita51@hotmail.com

Received: April 7, 2021 Accepted: May 23, 2021 Published: May 25, 2021

doi:10.5296/jas.v9i2.18503 URL: https://doi.org/10.5296/jas.v9i2.18503 


\section{Abstract}

This study evaluated the soil seed bank's germination potential and density in five distinct environmental areas namely: a) regenerated forest, b) secondary forest, c) degraded pasture, d) Eucalyptus sp. plantation and e) fallow corn growing area, with a view to regenerate forests in Western Amazonia using tray germination methodology. We assessed floristic similarity and diversity using the Jaccard Similarity Index and the Shannon Diversity Index, respectively. We computed each species' phytosociological parameters: density, frequency and importance value of each species. We recorded a total 3674 individuals from 51 species and 21 families. The families with the highest species richness were Asteraceae, Malvaceae, Cyperaceae and Poaceae that contributed to $43 \%$ of the total species observed. The most important species computed in the phytosociological analysis were Chamaesyce hirta, Corchorus aestuans, Cyperus iria and Chamaesyce prostrata. All species had a herbaceous life form, which in the literature, are considered weeds. We documented the largest number of individuals in the fallow corn growing area that had 3620 plants $\mathrm{m}^{-2}$ and the smallest number in the regenerated forest that had 183 plants $\mathrm{m}^{-2}$. We observed the greatest floristic similarity between the secondary forest and Eucalyptus sp. plantation (40\%), and the greatest floristic diversity in the Eucalyptus sp. plantation $\left(\mathrm{H}^{\prime}=2.59\right.$ nats individual $\left.^{-1}\right)$. In conclusion, the transposition of the soil seed bank is not recommended for forest regeneration and recovery in degraded areas due to massive weed predominance in the soil seed bank.

Keywords: degraded area, ecological succession, nucleation, soil recovery, restoration ecology

\section{Introduction}

Transposition of soil seed bank (SSB) stands out among techniques used to restore degraded areas. This technique describes the removal topsoil from a conserved area and its deposition in a degraded area with the same plant typology (Boanares \& Azevedo, 2014, Reis et al., 2014, Bechara et al. 2016, He et al., 2016, Ribeiro et al., 2017).

The SSB is a collection of viable seeds present on the surface of and inside the soil. The SSB can support vegetation regeneration in degraded areas by introducing an abundance of nutrients, increasing species' diversity, and enhancing conditions that facilitate the establishment of a new successional standard (Martins, 2018).

Using SSB transposition to restore an environment is based on the nucleation concept. Nucleation uses the biotic and abiotic elements in a small diversity nucleus that contains a micro-habitat to generate a new series of random successions. Nucleation promotes ecological propellants and enhances the probability of forming diverse random succession routes (Reis et al., 2014, Martins, 2018).

Nucleation is a relatively quick and low-cost assessment that can provide data on natural regeneration and define strategies to accelerate ecological succession processes in restored areas (Martins, 2018).

However, transposition requires meticulous evaluation of the SSB for its floristic composition 
and diversity, similarity to other areas, and its phytosiological parameters such as each species' density, frequency and importance value.

Preliminarily evaluating the SSB illustrates its natural regeneration potential since a predominance of weed species' seeds can negatively influence the agroecosystem's future composition and functioning (Skowronek et al., 2014).

The distribution and occurrence of most weeds in degraded areas is dependent on the combined effect of climate, and soil and relief and management practices (Santos et al. 2020).

Weeds interfere in agroecosystems by competing with cultivated crops for nutrients, water, light and space. Moreover, many weed species possess allelopathy mechanisms that hinder or prevent the growth of other plant/weed species.

Several studies have proved that SSB transposition is a viable alternative to forest regeneration in abandoned pastures and other degraded areas (Bechara et al. 2016, Santos et al. 2016, Piaia et al. 2017, Ribeiro et al, 2017, Martins 2018, Oliveira et al., 2018, Santos et al. 2020). However, little is known about the use of seed bank transposition as an environmental restoration tool in western Amazonia.

Therefore, this study evaluated the seed bank's germination and density, potential and its floristic composition, similarity, diversity and performed a phytosociological analysis in five different areas with distinct environmental conditions located in western Amazonia

\section{Methods}

\subsection{Characteristics the Study Area}

The research was carried out in in three rural areas located at the following coordinates: $4^{\circ} 57^{\prime} 56.43^{\prime \prime}$ $\mathrm{S}$ and $47^{\circ} 20^{\prime} 3.41^{\prime \prime} \mathrm{W} ; 4^{\circ} 56^{\prime} 54.20^{\prime \prime} \mathrm{S}$ and $47^{\circ} 22^{\prime} 32.50^{\prime \prime} \mathrm{W}$; and $4^{\circ} 59^{\prime} 51.60^{\prime \prime} \mathrm{S}$ and 47 $17^{\prime} 59.90^{\prime \prime} \mathrm{W}$, in Açailândia municipality, state of Maranhão, in western Amazonia (Figure 1).

The region presents irregular relief and has an average altitude of $200 \mathrm{~m}$. According to the Köppen classification, the region has an Aw tropical climate with an annual average temperature of $25.9^{\circ} \mathrm{C}$ and an average annual rainfall of $1334 \mathrm{~mm}$ (EDS QGIS, 3.6.1, 2019). Moreover, the region's soils are Red Yellow Latosol and Dystrophic Red Yellow Argisol soils (EMBRAPA, 2018).
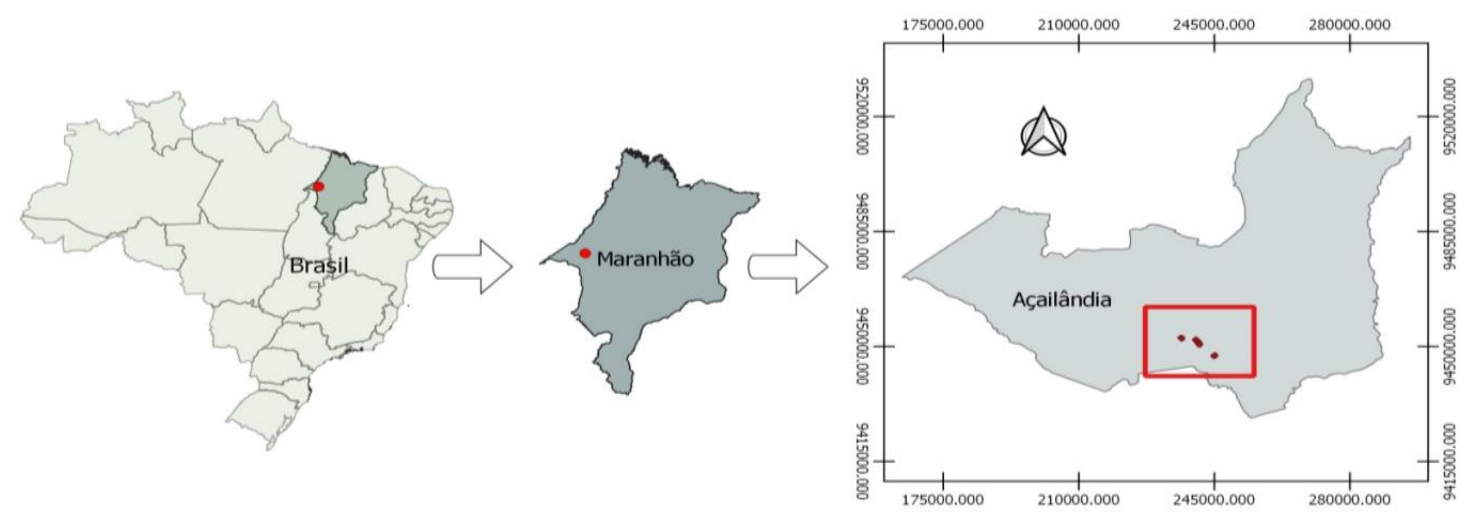
Figure 1. Location map of sample points, municipality of Açailândia, state of Maranhão, western Amazonia, 2019

\subsection{Evaluation of the Soil Seed Bank}

A transect following the relief slope was marked in each area with a GPS (Garmin Etrex 10®). A soil sample measuring $16 \mathrm{~cm} \times 25 \mathrm{~cm} \times 5 \mathrm{~cm}$ was collected using a metallic template at 50 m-intervals. We collected 15 soil samples in each environmental situation. In areas with thick herbaceous vegetation where it was difficult to collect a sample, the ground was manually cut and roots and cuttings removed from the soil's surface.

The soil samples were placed in plastic bags which were then labelled and transported to a plastic greenhouse. In the greenhouse, labelled samples were placed in high density polyethylene trays measuring $30.3 \mathrm{~cm}$ long, $22.1 \mathrm{~cm}$ wide and $7.5 \mathrm{~cm}$ deep. Holes had been drilled into the trays to facilitate drainage.

\subsection{Experimental Design}

The experiment was laid out in a randomized complete design with five treatments and 15 replications. The treatments were: regenerated forest (T1), secondary vegetation (T2), degraded pasture (T3), Eucalyptus sp. plantation (T4) and fallow corn growing area (T5).

The experiment was carried out in a plastic greenhouse with a 150 micra thick polyethylene cover and side shade protection with a $50 \%$ shading rate. The greenhouse was located at the Technological Diffusion Center, in the municipality of Imperatriz, State of Maranhão. Irrigation was carried out by means of an automatic micro-sprinkler system, with operating timer at five-minutes intervals at 8:00 am, 12:00 pm and 6:00 pm, during 150 days.

Germination was carried out in trays. Every 15 days, germinated seedlings were identified, counted, and subsequently removed from the trays. The research team made ten evaluations over a period of 150 days.

Species were identified by comparing them with known species in published literature (Lorenzi, 2014). The species that could not be identified were transplanted into tubes and grown until the flowering stage. The flowers were then used to identify the species. We organized the floristic composition according to Angiosperm Phylogeny Group IV' classification system (APG IV, 2016).

\subsection{Statistical Analyses}

We used the Shapiro-Wilk normality test to assess data for normality and the Bartlett homogeneity tests of variance to compare variances between groups. These tests were carried out at 5\% probability before assessing the possibility of performing an Analysis of Variance (ANOVA) test. However, when normality and homogeneity of variance were rejected, we performed the Kruskal-Wallis non-parametric test, followed by Nemenyi's post-hoc test (Emmerling, 2014) for multiple comparisons using the SAS statistical program (SAS, 2000), at $5 \%$ probability.

Additionally, we assessed for floristic similarity in the five areas by means of the Jaccard 
Similarity Index using the Past 3.25 software (Hamer et al., 2001). Floristic diversity was assessed using the Shannon Diversity Index (Mesquita et al. 2016, Amorim \& Mesquita, 2019).

We computed the following phytosociological parameters to analyze the plant community: frequency to describe species' distribution in the plots; density of individuals of each species per unit area and the relative frequency and relative density of each species found in the area. The importance value indicates which species are more important within the studied area (MullerDombois \& Ellenberg, 1974).

\section{Results and Discussion}

\subsection{Floristic Composition}

In total, there were 3674 individuals belonging to 51 species and 21 families. All species had a herbaceous life form (Table 1).

Herbaceous species predominate in regenerated degraded areas and in recovering forests due to their more open canopy. Such areas include anthropized areas that have a fallow interval, and secondary vegetation (Piaia et al. 2017, Duarte et al. 2019, Santos et al., 2020).

This study areas had numerous anthropization characteristics ranging from cut large arboreal individuals, burnt areas, and no regard to preserve soil fertility before planting pastures, and a greater susceptibility to erosion processes. These characteristics may have facilitated herbaceous species' invasion.

Oliveira et al. (2018) found results similar to those of this study; they had 20 families and 36 species emerging from the same depth used in our study indicating that even in soil profiles from shallow depths have a significant amount of viable seeds (Table 1).

In a different research study carried out with different successional stages in a degraded area, the dominant species in all treatments also had a herbaceous life form. These results corroborate the results of the present study (Bechara, et al. 2016, Piaia et al. 2017, Santos et al., 2020).

In this study, the families with the highest number of species were Asteraceae and Malvaceae with six species each, followed by Cyperaceae and Poaceae with five species each. These four families contributed to $43 \%$ of the all the species in this study (Table 1).

Piaia et al. (2017) recorded the predominance of pioneer herbaceous species with greater representation of the Poaceae, Asteraceae and Solanaceae families in soil seed bank fragments from seasonal forests and stabilized gullet. Similar results were reported by Deiss et al. (2018) regarding the Eucalyptus dunnii Maiden plantation.

The species F. dichotoma, $C$. hirta, C. prostrata, $C$. mucunoides $C$. aestuans and $H$. communis were observed in all the SSB's evaluated environments, showing their great plasticity, that is, their ability to adapt different environments (Table 1).

Table 1. List of species, families, common names and number of individuals, identified in the soil seed bank in areas with five environmental situations: regenerated forest (T1), secondary 
vegetation (T2), degraded pasture (T3), Eucalyptus sp. plantation (T4) and fallow corn growing area (T5) in the municipality of Açailandia, state of Maranhão, western Amazonia

Species

Family

Common name

Number of individuals

$\mathrm{T} 1 \mathrm{~T} 2 \quad \mathrm{~T} 3 \quad \mathrm{~T} 4 \quad \mathrm{~T} 5$

\begin{tabular}{|c|c|c|c|c|c|c|c|}
\hline $\begin{array}{l}\text { Amaranthus } \\
\text { deflexus L. }\end{array}$ & AMARANTHACEAE & Bredo & - & 1 & - & - & 2 \\
\hline $\begin{array}{l}\text { Amaranthus } \\
\text { hybridus } \quad \text { var. } \\
\text { patulus }\end{array}$ & AMARANTHACEAE & Bredo & - & - & - & - & 7 \\
\hline (Betol.) Thell. & & & & & & & \\
\hline Amaranthus sp. & AMARANTHACEAE & Amaranto & 12 & 3 & - & - & - \\
\hline Bidens pilosa $\mathrm{L}$. & ASTERACEAE & Picão Preto & - & 4 & - & - & - \\
\hline $\begin{array}{l}\text { Eclipta alba (L.) } \\
\text { Hassk. }\end{array}$ & ASTERACEAE & Erva de botão & - & 9 & 9 & 4 & 117 \\
\hline $\begin{array}{l}\text { Hypochaeris } \\
\text { radicata } \mathrm{L} \text {. }\end{array}$ & ASTERACEAE & $\begin{array}{l}\text { Almeirão do } \\
\text { campo }\end{array}$ & - & 1 & - & - & - \\
\hline $\begin{array}{l}\text { Parthenium } \\
\text { hysterophorus L. }\end{array}$ & ASTERACEAE & Losna branca & 8 & - & - & 10 & - \\
\hline $\begin{array}{l}\text { Synedrellopsis } \\
\text { grisebachii }\end{array}$ & ASTERACEAE & Agriãozinho & - & 2 & 2 & - & 7 \\
\hline $\begin{array}{l}\text { Hieron. } \quad \& \\
\text { Kuntze }\end{array}$ & & & & & & & \\
\hline $\begin{array}{l}\text { Vernonia } \\
\text { ferrugínea Less. }\end{array}$ & ASTERACEAE & Assa peixe & - & - & - & 3 & - \\
\hline $\begin{array}{l}\text { Commelina } \\
\text { benghalensis L. }\end{array}$ & COMMELINACEAE & Trapoeraba & 1 & 6 & - & 2 & 23 \\
\hline $\begin{array}{l}\text { Commelina } \\
\text { difusa Burm. } \mathrm{f} .\end{array}$ & COMMELINACEAE & Trapoeraba & - & 9 & 28 & - & - \\
\hline
\end{tabular}


Ipomoea cairica CONVOLVULACEAE Jetirana

(L.) Sweet

Ipomoea

purpúrea

Roth

Ipomoea

ramosíssima

(Poit.) Choisy

Ipomoea $\mathrm{sp.}$

Cyperus

difformis $L$.

Cyperus

CYPERACEAE

hermaphroditus

(Jacq.) Standl

Cyperus iria $\mathrm{L}$.

Fimbristylis

dichotoma

(L.)

Vahl

Fimbristylis

miliacea

Vahl

Chamaesyce

hirta (L.) Millsp.

Chamaesyce

prostrata (Aiton)

Small

Croton lundianus

EUPHORBIACEAE Gervão branco

(Didr.) Müll. Arg.

Euphorbia sp.

CONVOLVULACEAE Corda de Viola

CONVOLVULACEAE Campainha

CONVOLVULACEAE Corda de Viola

Tiririca

Tiririca

Titirica

dias

Cuminho

$$
\text { CYPERACEAE }
$$

Cuminho

(L.)

\section{EUPHORBIACEAE}

Erva

Luzia

EUPHORBIACEAE Baldroega E

-
$-\quad 16 \quad 1$

$\begin{array}{llll}- & 32 & 278 \quad 22 \quad 340\end{array}$

Grama de oito

$\begin{array}{ll}30 & 48\end{array}$

$13 \quad 73$

$\begin{array}{llll}4 & 10 & 31 & 94\end{array}$

74 
Calopogonium

FABACEAE

Calopogonio

$\begin{array}{lllll}1 & 15 & 27 & 6 & 10\end{array}$

mucunoides

Desv.

Mimosa pudica FABACEAE

Dormideira

- $\quad-\quad-\quad 4 \quad 2$

L.

\begin{tabular}{llllllll}
$\begin{array}{l}\text { Corchorus } \\
\text { aestuans L. }\end{array}$ & MALVACEAE & Juta & 4 & 390 & 149 & 18 & 574 \\
Sida glaziovii & MALVACEAE & Guanxuma-branca & - & 2 & - & 17 & 1 \\
\hline Species & Famíly & Common name & & Number of indivíduals
\end{tabular}

$\begin{array}{lllll}\mathrm{T} 1 & \mathrm{~T} 2 & \mathrm{~T} 3 & \mathrm{~T} 4 & \mathrm{~T} 5\end{array}$

Continuing Table

$1 \ldots$

Sida rhombifolia MALVACEAE

Vassourinha

$\begin{array}{lllll}- & 3 & 21 & 14 & 16\end{array}$

L.

Sida spinosa L. MALVACEAE

Guaxuma

de $\quad-\quad-\quad-8$

espinho

Sida sp.

MALVACEAE

Guaxuma

$9 \quad 16$

Urena lobata L. MALVACEAE

Caquibosa

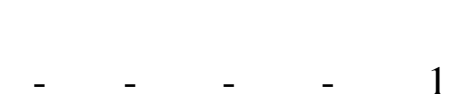

Mollugo

MOLLUGINACEAE

Capim tapete

$-$

$\begin{array}{lll}8 & 9 & 3\end{array}$

77

verticillata $\mathrm{L}$.

Ludwigia

ONAGRACEAE

Cruz de Malta

$$
11
$$

leptocarpa

(Nutt.) H. Hara

Phyllanthus

PHYLLANTHACEAE Quebra pedra

$\begin{array}{lll}- & 14 & 9\end{array}$

69

niruri L.

Lindernia

$$
\text { PLANTAGINACEAE Capim tapete }
$$

12

69

crustacea (L.) F.

Muell. 
Brachiaria sp. POACEAE

Brachiaria

$12 \quad 10$

Cynodon

POACEAE

Grama seda

dactylon

(L.)

Pers.

\section{Digitaria}

POACEAE

Capim colchão

2

horizontalis

Willd.

Digitaria sp.

POACEAE

Capim Colchão

Eleusine indica POACEAE

Capim pé de $\quad \begin{array}{llllll} & 2 & 21 & 4 & 41\end{array}$

(L.) Gaertn.

galinha

Portulaca

PORTULACACEAE

Baldroega

$\begin{array}{lll}- & 3 & 4\end{array}$

212

oleraceae L.

Spermacoe

RUBIACEAE

Vassourinha

4

13

verticilata $\mathrm{L}$.

Diodia

RUBIACEAE

Poia do brejo

12

18

saponariifolia

(Cham.

$\&$

Schltdl.)

$\mathrm{K}$.

Schum.

\section{Mitracarpus}

RUBIACEAE

Poia

hirtus (L.) DC.

Physalis

SOLANACEAE

Camapú

angulata $\mathrm{L}$.

Turnera subulata

TURNERACEAE

Albina

4

Sm.

Hybanthus

VIOLACEAE

Bandeira branca

24

3

communis (A St.-

Hil.) Taub.

Unidentified

$-\quad 3189$

species 
Total of species

Total of

indivíduals

The species $F$. dichotoma, $C$. hirta, $C$. prostrata, $C$. mucunoides $C$. aestuans and $H$. communis were observed in all evaluated environmental situations showing their great plasticity (i.e. their ability to adapt different environments) (Table 1). In contrast, the species I. purpurea was only observed in T1 (regenerated forest), the species Bidens sp., H. radiata, Euphorbia sp. and $P$. angulata only found in T2 (secondary vegetation), the species $V$. ferruginea and $S$. spinosa in T4 (Eucalyptus sp. plantation), and the species A. hybridus in T5 (fallow corn growing area) (Table 1).

The highest seedling emergence flows were observed 15, 45 and 90 days after the start of the study in all treatments except T1 (Figure 2).

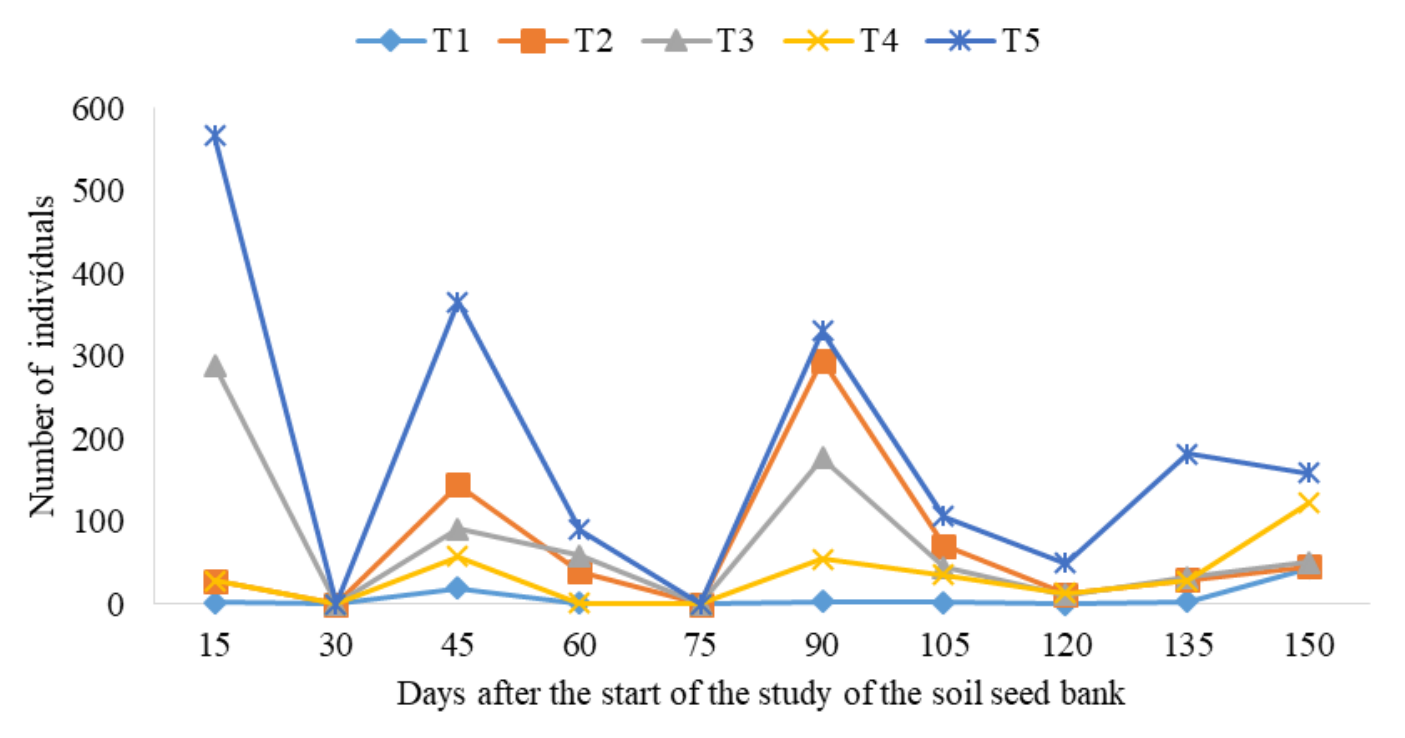

Figure 2. Number of individuals recorded in the soil seed bank during the period of 150 days of evaluation in five environment situations: regenerated forest (T1), secondary vegetation (T2), degraded pasture (T3), Eucalyptus sp. plantation (T4) and fallow corn growing area (T5)

Differences in the number of germinated individuals over time are due to the precipitation pulses at the beginning of the rainy season that trigger seed germination in the SSB.

\subsection{Floristic Similarity}

The Jaccard Similarity Index demonstrated a greatest floristic similarity between T2 and T4 treatments probably due to their geographic proximity and similar climate and soil conditions. The T1 treatment is the most distinct treatment used in this study (Figure 2). 


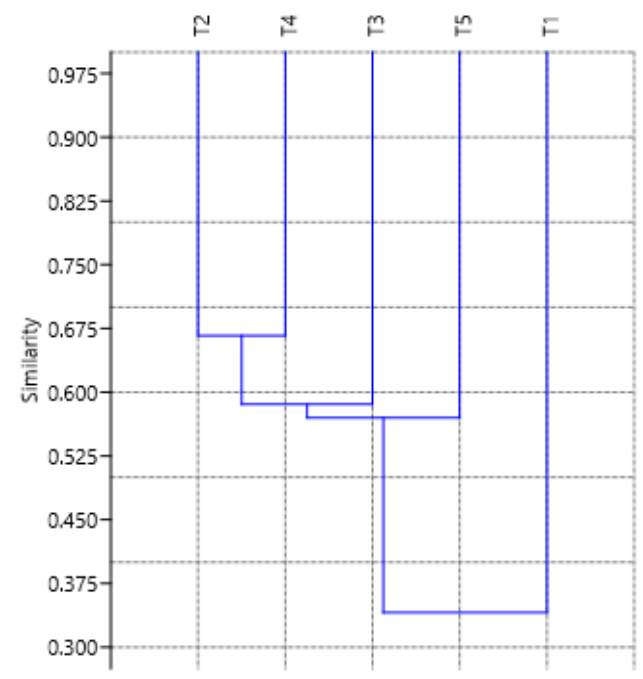

Figure 2. Dendrogram with the Jaccard Similarity Index in five environmental situations: regenerated forest (T1), secondary vegetation (T2), degraded pasture (T3), Eucalyptus sp. plantation (T4) and fallow corn growing area (T5)

\subsection{Floristic Diversity}

Based on the Shannon Diversity Index, floristic diversity was highest in the Eucalyptus sp. plantation $\left(\mathrm{H}^{\prime}=2.59\right.$ nats individual $\left.{ }^{-1}\right)$ followed by the fallow corn growing area $\left(\mathrm{H}^{\prime}=2.32\right)$, degraded pasture $\left(\mathrm{H}^{\prime}=2.21\right)$, forest remnant $\left(\mathrm{H}^{\prime}=2.16\right)$ and secondary vegetation $\left(\mathrm{H}^{\prime}=1.82\right.$ nats individual ${ }^{-1}$ ). Similarly, Ribeiro et al. (2017) reported that the Diversity Index in planted areas was higher than the Diversity Index in degraded areas.

Based on results of the Kruskal-Wallis non-parametric test and the Nemenyi's post-hoc test for multiple comparisons, the number of individuals was highest in the fallow corn cultivation area; this difference was statistically significant (Table 2).

Table 2. Comparison between treatments regarding the number of individuals $\mathrm{m}^{-2}$

\begin{tabular}{ccc}
\hline Treatment & SD & Mean \\
\hline 1 & 13,76 & $7,30 \mathrm{~b}$ \\
2 & 90,77 & $66,30 \mathrm{a} \mathrm{b}$ \\
3 & 91,61 & $75,20 \mathrm{a} \mathrm{b}$ \\
4 & 37,40 & $33,80 \mathrm{ab}$ \\
5 & 183,38 & $184,80 \mathrm{a}$ \\
\hline
\end{tabular}


Test statistics a,b

Ind

Chi-square

11,770

SD - Standard deviation

4

Significance Sig.

, 019

Means with different letters differ by the multiple comparison of Nemenyi test at 5\% significance

$\mathrm{SD}=$ Standard deviation

The seed bank in the preserved environment compared to areas in the process of degradation or intensive management are divergent in wealth and abundance.

The statistical analysis also showed a significant difference in the number of individuals $\mathrm{p}=$ 0.019 ( $\mathrm{p}<0.05$ ) and confirmed that the total density of viable seeds in the soil seed bank tends to decrease with advances in ecological succession from restoration techniques.

\subsection{Phytosociological Analyses}

The germination density in the soil seed bank was recorded as 3,620 plants $\mathrm{m}^{-2}$ in $\mathrm{T} 5,1,813$ plants $\mathrm{m}^{-2}$ in T3, 1,676 plants $\mathrm{m}^{-2}$ in $\mathrm{T} 2,845$ plants $\mathrm{m}^{-2}$ in $\mathrm{T} 4$ and 183 plants $\mathrm{m}^{-2}$ in $\mathrm{T} 1$.

These results concur with reports by Schorn et al. (2013) that showed 2,846 individuals $\mathrm{m}^{-2}$ for remaining environments, 4,292 individuals $\mathrm{m}^{-2}$ for fallow areas of forest with eucalyptus plants, and 2,125 individuals $\mathrm{m}^{-2}$ for area reforested using Pinnus sp.

The result of the phytosociological analysis showed that only six species had a high Importance Value and thus stood out as the dominant species. The importance value (IV) numerically expresses the importance of a given species in a community (Müeller-Dombois \& Ellenberg, 1974). (Table 3)

Table 3. Relative density, relative frequency and importance value of the six major species recorded in the soil seedbank in five environmental situations in the western Amazon

\begin{tabular}{cccc}
\hline \multicolumn{4}{c}{ Regenerated forest } \\
Species & RD & RF & IV \\
\hline Chamaesyce hirta & 31.5 & 33.6 & 65.1 \\
Sida sp. & 12.3 & 10.5 & 22.8 \\
Amaranthus sp. & 16.4 & 2.7 & 19.1 \\
Parthenium hysterophorus & 10.9 & 5.5 & 16.4 \\
Fimbristylis dichotoma & 4.1 & 11.1 & 15.3 \\
Chamaesyce prostrata & 5.4 & 5.5 & 10.9
\end{tabular}

Secondary forest 


\begin{tabular}{cccc}
\hline Species & $\mathrm{RD}$ & $\mathrm{RF}$ & $\mathrm{IV}$ \\
\hline Corchorus aestuans & 58.8 & 26.1 & 84.9 \\
Chamaesyce hirta & 10.1 & 10.1 & 20.2 \\
Fimbritylis dichotoma & 4.4 & 6.9 & 11.3 \\
Cyperus iria & 4.8 & 3.7 & 8.5 \\
Calopogonium mucunoides & 2.2 & 4.8 & 7.0 \\
Bidens sp. & 0.6 & 6.4 & 7.0 \\
\hline Species & Degraded pasture & & \\
\hline Cyperus iria. & $\mathrm{RD}$ & $\mathrm{RF}$ & $\mathrm{IV}$ \\
\hline Corchorus aestuans & 36.9 & 13.7 & 50.6 \\
Fimbristylis dichotoma & 19.3 & 13.0 & 32.3 \\
Chamaesyce hirta & 6.3 & 13.0 & 19.4 \\
Calopogonium mucunoides & 5.0 & 9.8 & 14.8 \\
Chamaesyce. Prostrata & 3.5 & 9.8 & 13.3 \\
\hline
\end{tabular}

\begin{tabular}{cccc}
\hline \multicolumn{4}{c}{ Eucalyptus sp. plantation } \\
\hline Species & RD & RF & IV \\
\hline Chamaesyce prostrata & 27.8 & 16.0 & 43.8 \\
Chamaesyce hirta & 16.5 & 14.8 & 31.3 \\
Cyperus iria & 6.5 & 7.4 & 13.9 \\
Corchorus aestuans & 5.3 & 7.4 & 12.7 \\
Fimbristylis dichotoma & 3.8 & 6.1 & 9.9 \\
Sida glaziovii & 5.0 & 3.7 & 8.7 \\
\hline
\end{tabular}

\begin{tabular}{cccc}
\hline \multicolumn{4}{c}{ Fallow corn growing area } \\
\hline Species & RD & RF & IV \\
\hline Corchorus aestuans & 31.0 & 15.1 & 46.1 \\
Cyperus iria & 18.3 & 7.5 & 25.8 \\
Portulaca oleracea & 11.4 & 13.9 & 25.3 \\
Phyllanthus niruri & 3.7 & 9.2 & 12.9 \\
Lindernia crustacea & 2.4 & 9.2 & 11.6 \\
Chamaesyce hirta & 6.2 & 5.0 & 11.2 \\
\hline
\end{tabular}

The species $C$. hirta was among the six dominant species in the seed bank in all areas, while other species portrayed similar behavior in all except one area, for example, C. aestuans was nondominant in T1, F. dichotoma in T5 and Cyperus iria in T1.

All this study's dominant species are exclusively propagated by seeds. However, $F$. dichotoma (Cyperaceae) is also propagate asexually using rhizomes (Lorenzi, 2008). 
The species' dominance in soil seedbank is related not only to the area's history, but also to the species' reproductive capacity. For instance, Fimbristylis dichotoma (L.) Vahl can produce 6500 seeds per plant, while Cyperus iria (L.) can produce 5000 seeds per plant (Thompson et al. 2003).

Weeds characteristically produce a very high number of seeds to ensure species' survival and escape stresses imposed by weed-control methods.

The analyzes carried out show that in a $5 \mathrm{~cm}$ profile tray, herbaceous species, considered weeds or invasive plants, prevailed at the end of an emergency. This demonstrates that small seeds, characteristic of weed species, have adaptive advantages such as low predation and ease of incorporation into the soil (Santos et al. 2020).

The fact that trees and shrubs did not germinate can be linked to environmental fragmentation, seasonality (Santos et al. 2020) and floods in riparian forest areas that remove and bury the soil's seed bank (Araújo et al., 2004).

Despite challenges in understanding the entire ecological succession process and how to apply technical knowledge to facilitate recovery processes, further research should focus on the SSB's dynamics over longer germination assessment periods to support planning and executing soil transposition for successful ecological restoration.

\section{Conclusions}

In a regenerated forest, or degraded pasture, secondary forest, Eucalyptus sp. plantation and fallow corn growing areas in Western Amazonia the composition, similarity and floristic diversity of soil seed bank is formed by species of herbaceous life form considered in the literature as weeds with an invasive character, with no more seeds left of shrub-tree species deposited in the seed bank.

Therefore, SSB transposition as a nucleation technique cannot be used to regenerate Western Amazonian forests in areas similar to those we studied.

Alternative complementary interventions, such as planting seedlings and / or direct sowing of native tree species should be used to accelerate plant succession.

Further studies employing alternative nucleation techniques should be conducted to support forest regeneration in Western Amazonia.

\section{Aknowledgments}

The authors thank to the Fundação de Amparo à Pesquisa e ao Desenvolvimento Científico e Tecnológico do Maranhão (FAPEMA) for granting a scholarship to the first author.

\section{References}

Adeux, G., Vieren, E., Carlesi, S., Bàrberi, P., Munier-Jolain, N., \& Cordeau, S. (2019). Mitigating crop yield losses through weed diversity. Nature Sustainability, 2, 1018-1026. https://doi.org/10.1038/s41893-019-0415-y 
Amorim, D., \& Mesquita, M. L. R. (2019). Floristic composition, phytosociology and weed diversity in chives (Allium schoenoprasum L.). Revista Brasileira de Ciências Agrárias, 14(3), e5663. https://doi.org/10.5039/agraria.v14i3a5663

Angiosperm Phylogeny Group - APG. (2016). An update of the Angiosperm Phylogeny Group classification for the orders and families of flowering plants: APG IV. Botanical Journal of the Linnean Society, 181(1), 1-20. https://doi.org/10.1111/boj.12385

Araújo, M. M., Longui, S. J., Barros, P. L. C., \& Brena, D. A. (2004). Caracterização da chuva de sementes e banco de sementes do solo e banco de plântulas em Floresta Estacional, Decidual ripária Cachoeira do Sul, RS, Brasil. Scientia Florestalis, 66, 128-141. https://www.ipef.br/publicacoes/scientia/nr66/cap13.pdf

Bechara, F. C., Dickens, S. J., \& Farrer, E. C. (2016). Neotropical rainforest restoration: comparing passive, plantation and nucleation approaches. Biodiversity and Conservation, 25, 2021-2034. https://doi.org/10.1007/s10531-016-1186-7

Boanares, D., \& Azevedo, C. S. (2024). The use of nucleation techniques to restore the environment: a bibliometric analysis. Natureza e Conservação, 2, 93-98. https://doi.org/10.1016/j.ncon.2014.09.002

Deiss, L., Moraes, A., Pelissari, A., Porfírio-da-Silva, V., Schuster, M. Z. (2018). Weed seed bank in an agroforestry system with eucalyptus in subtropical Brazil. Planta Daninha, 3. e018162465. https://doi.org/10.1590/s0100-83582018360100022

Duarte, S. W., Hoffmann, L. T., Maçaneiro, J. P., Fenilli, T. A. B., \& Schorn, L. A. (2019). Effects of the environment and spatial factors on the regeneration of Araucaria Forest fragments, southern Brazil. Applied Ecology and Environmental Research, 17, 9577-9589, https://doi.org/10.15666/aeer/1704_95779589

Emmerling, C. (2014). Impact of land-use change towards perennial energy crops on $\begin{array}{llll}\text { earthworm } \quad \text { population. } & \text { Applied } & \text { Ecology, }\end{array}$ https://doi.org/10.1016/j.apsoil.2014.06.006

Empresa Brasileira de Pesquisa Agropecuária. (2018). Sistema brasileiro de classificação de solos. Rio de Janeiro: EMBRAPA, $5^{\text {a }}$ edição https://www.embrapa.br/busca-de-publicacoes/-/publicacao/1094003/sistema-brasileiro-de-cl assificacao-de-solos

Equipe de Desenvolvimento do QGIS. (20219). Sistema de Informações Geográficas do QGIS. Projeto Código Aberto Geospatial Foundation. http://qgis.osgeo.org.

He, M., Ly, L., Li, H., Meng, W., \& Zhao N. (2016). Analysis on Soil Seed Bank Diversity Characteristics and Its Relation with Soil Physical and Chemical Properties after Substrate Addition. PLoS ONE 11 e0147439. https://doi.org/10.1371/journal.pone.0147439

Lorenzi, H. (2014). Manual de Identificação e controle de plantas daninhas: Plantio direto e

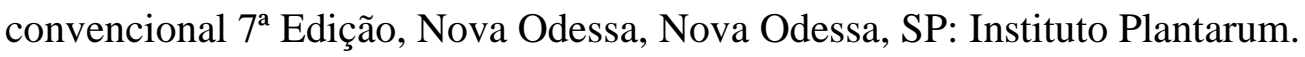


Marteinsdóttir, B. (2014). Seed rain and seed bank reveal that seed limitation strongly influences plant community assembly in grasslands PlosOne, 9(7), 1-8, https://doi.org/10.1371/journal.pone.0103352

Martins, S. B. (2018). Alternative Forest Restoration Techniques. In New Perspectives in Forest Science. Chapter 7. IntechOpen. 131-148, https://doi.org/10.5772/intechopen.72908

Mesquita, M. L. R., Andrade, L. A., \& Pereira, W. E. (2016). Germination, floristic composition and phytosociology of the weed seed bank in rice interropped with corn fields. Agrária - Revista Brasileira de Ciências Agrárias, 11(1), 14-20. https://doi.org/10.5039/agraria.v11i1a5359

Mueller-Dombois D., \& Ellenberg, H. (1974). Aim sand methods of vegetation ecology. Nova York: John Wiley and Sons.

Oliveira, T. J. F., Barroso, D. G., Andrade, A. G., Freitas, I. L. J., \& Amim, R. T. (2018). Banco de sementes do solo para uso na recuperação de matas ciliares degradadas na região noroeste fluminense. Ciência Florestal, 28, 206-217. https://doi.org/10.5902/1980509831653

Piaia, B. B., Rovedder, A. P. M., Stefanello, M. M., Felker, R. M., \& Piazza, E. M. (2017). Análise do banco de sementes visando estratégia de transposição para a restauração ecológica no Rio Grande do Sul. Floresta, 47(3), 221-228. https://doi.org/10.5380/rf.v47i3.46842

Reis, A., Bechara, F. C., Tres, D. R., \& Trentin, B. E. (2014). Nucleação: concepção biocêntrica para a restauração ecológica. Ciência Florestal, 24(2), 509-518. https://doi.org/10.5902/1980509814591

Reis, D. N., David, E. A. C., \& Ferreira, D. F. (2014). Indicadores preliminares para avaliação da restauração em reflorestamentos de ambientes ciliares. Pesquisa Florestal Brasileira, 34(80), 375-389. https://doi.org/10.4336/2014.pfb.34.80.757

Ribeiro, T. O., Bakke, I. A., Souto, P. C., Bakke, O A., \& Lucena, D. S. (2017). Diversidade do Banco de Sementes em diferentes áreas de caatinga manejadas no semiárido da Paraíba, Brasil. Ciência Florestal, 27(1), 203-213. https://doi.org/10.5902/1980509826459

Santos, A. M. S., Bruno, R. L. A., Cruz, J. O., Silva, I. F., \& Andrade, A. P. (2020). Variabilidade espacial do banco de sementes em área de Caatinga no Nordeste do Brasil. Ciência Florestal, 30(2), 542-555. https://doi.org/10.5902/1980509840039

Santos, D. M., Santos, J. M. F. F., Silva, K. A., Araújo, V. K. R., \& Araújo, E. L. (2016). Composition, species richness, and density of the germinable seed bank over 4 years in young and mature forests in Brazilian semiarid regions. Journal of Arid Environments, 129, 93-101. https://doi.org/10.1016/j.jaridenv.2016.02.012

Schorn, L. A., Fenilli, T. A. B., Krüger, A., Pellens, G. C., Budag, J. J., \& Nadolny, M. C. (2013). Composição do banco de sementes no solo em áreas de preservação permanente sob diferentes tipos de cobertura. Floresta, 43(1), 49-58. https://doi.org/10.5380/rf.v43i1.21493

Skowronek, S., Terwei A., Zerbe S., Molder, I., Annighofer, P., Kawaletz H et al. (2014). 


\section{Macrothink}

Journal of Agricultural Studies

ISSN 2166-0379 2021, Vol. 9, No. 2

Regeneration Potential of Floodplain Forests Under the Influence of Nonnative Tree Species: Soil Seed Bank Analysis in Northern Italy. Restoration Ecology; 22(1), 22-30. https://doi.org/10.1111/rec.12027

Statistical Analysis System - SAS. (2000). SAS software: user's guide. Version 8.2. Cary

Thompson, K., Ceriani, R. M., Bakker J. P., \& Bekker, R. M. (2003). Are seed dormancy and persistence in soil related? Seed Science Research. 13, 97-100. https://doi.org/10.1079/SSR2003128

\section{Copyright Disclaimer}

Copyright for this article is retained by the author(s), with first publication rights granted to the journal.

This is an open-access article distributed under the terms and conditions of the Creative Commons Attribution license (http://creativecommons.org/licenses/by/4.0/). 